\title{
BIOAVAILABILITY STUDY OF SAMBILOTO (Andrographis paniculata) HERBS INFUSION IN RABBIT
}

\author{
Jutti Levita*1 ${ }^{1}$, Hetsa Himawati ${ }^{1}$, Rizky Vitriani Lukman ${ }^{1}$, Melysa Afdila ${ }^{1}$, Holis Abdul \\ Holik $^{1}$, Nyi Mekar Saptarini ${ }^{1}$, Aliya Nur Hasanah ${ }^{1}$, As'ari Nawawi $^{2}$, Abdul Mutalib ${ }^{3}$, \\ Slamet Ibrahim ${ }^{2}$
}

\begin{abstract}
1Dept. of Pharmaceutical Analysis and Medicinal Chemistry Faculty of Pharmacy Universitas Padjadjaran. Jl. Raya Bandung-Sumedang km.21 Jatinangor, Sumedang, West Java, Indonesia 45363 2School of Pharmacy Institut Teknologi Bandung Jl. Ganesha 10 Bandung West Java Indonesia ${ }^{3}$ Dept of Chemistry Faculty of Mathematics and Natural Sciences Universitas Padjadjaran. Jl. Raya Bandung-Sumedang km.21 Jatinangor, Sumedang, West Java, Indonesia 45363
\end{abstract}

Submitted: 04-02-2014 Revised: 20-04-2014 Accepted: $23-05-2014$

*Corresponding author Jutti Levita

Email :

jutti.levita@unpad.ac.id

\begin{abstract}
Andrographis paniculata or sambiloto is one of the most widely used medicinal herbs in Indonesia. The main bioactive chemical constituent, andrographolide, has been reported to have various pharmacological activities. Besides its function for medical purposes, the sambiloto herbs infusion is frequently taken to maintain health. This study was conducted to determine the bioavailability of sambiloto herbs infusion in rabbit plasma, stomach, and liver, calculated as total andrographolide. Fourteen male New Zealand white rabbits were used in this study. Sambiloto herbs infusion were administered orally at the dose $7.04 \mathrm{~mL} / \mathrm{kg}$ body weight to each rabbit. Blood samples were taken at intervals $0.0 ; 0.5 ; 1.5 ; 2.0 ; 3.0$; and 5.0h after infusion administration. Sambiloto herbs infusion, which are calculated as andrographolide, levels in plasma, stomach, and liver were analyzed by high performance liquid chromatography using C-18 column as stationary phase and a mixture of methanol-double distilled water $(60: 40)$ as mobile phase. Bioavailability parameters obtained were $C_{\max }$ $0.5549 \mu \mathrm{g} / \mathrm{mL}$ (in stomach), $0.2136 \mu \mathrm{g} / \mathrm{mL}$ (in plasma), $0.0051 \mu \mathrm{g} / \mathrm{mL}$ (in liver); while $\mathrm{t}_{\max } 1 \mathrm{~h}$ (in stomach), $1.5 \mathrm{~h}$ (in plasma), $2 \mathrm{~h}$ (in liver); and AUC $1.7451 \mu \mathrm{g} . \mathrm{h} / \mathrm{mL}$ (in stomach), $0.434 \mu \mathrm{g} . \mathrm{h} / \mathrm{mL}$ (in plasma), $0.0038 \mu \mathrm{g} . \mathrm{h} / \mathrm{mL}$ (in liver). These data showed that in healthy animals, sambiloto herbs infusion was fastly absorbed from the stomach, distributed in the circulation system, and metabolized in the liver, in subsequent process. Sambiloto herbs infusion showed good bioavailability in rabbit.
\end{abstract}

Key words: andrographolide, Andrographis paniculata, bioavailability, sambiloto

\section{INTRODUCTION}

Andrographis paniculata or sambiloto is one of the most widely used medicinal herbs in Indonesia. This plant also grows in many other Asian countries such as China, India, Thailand and Sri Lanka. It is particularly known for its extremely bitter properties and is used traditionally as a remedy against common cold, fever, inflammation, etc. The main bioactive chemical constituent, andrographolide, has been reported to have various pharmacological activities including anti-inflammatory via different mechanisms (Chiou et al., 2000; Shen et al., 2002; Satyanarayana et al., 2004; Xia et al., 2004; Abu-Ghefreh et al., 2009; Levita, et al, 2010), anticancer and antitumour (Satyanarayana et al., 2004; Shen et al., 2009). Besides its function for medical purposes, sambiloto herbs infusion is frequently used to maintain health.

Andrographolide, an active component of Andrographis paniculata, is the major labdane diterpenoidal constituent in this plant, which has an $\alpha$-alkylidene $\gamma$-butyrolactone, two olefin bonds at C8(17) and C12(13), and three hydroxyl groups at C3, C19, and C14 (Nanduri et al., 2004).

Bioavailability of drugs refers to the extent and rate at which the active moiety (drug or metabolite) enters systemic circulation, thereby accessing the site of action. Pharmacological response is related with drug concentration at the receptor, therefore bioavailability of drug is an important element a clinical pharmaceutical effects (Chereson, 1996).

Previous study on the determination of bioavailability parameters of andrographolide 
was performed by Budipramana and colleagues (2009). In their study, bioavailability of andrographolide in animal plasma was studied not from a single extract. Animals were treated with a mixture of ethanolic extracts of two plants (sambiloto and turmeric). They concluded that andrographolide was absorbed and distributed in blood within 60-90min and $\mathrm{C}_{\max }$ 3.06-4.41ppm (Budipramana, 2009).

Other bioavailability study of andrographolide, didehydroandrographolide, and neoandrographolide in rats showed $C_{\max } 1.76 \mu \mathrm{g} / \mathrm{mL}$ and $t_{\max } 2.04 \mathrm{~h}$ after oral administration, while didehydroandrographolide was fastly absorbed and neoandrographolide was very slow (Pinthong et al., 1991).

In this study, we determined the bioavailability of sambiloto herbs infusion, calculated as total andrographolide, the major component in the plant, using reversed-phase high performance liquid chromatography. Detection was set at ultraviolet wavelength, according to the compound's chromophores. Rabbit was chosen as tested animal. Measurement was carried out to rabbit plasma, stomach, and liver, calculated as total andrographolide.

\section{MATERIALS AND METHODS}

Andrographolide $98 \% \quad 500 \mathrm{mg} \quad$ CAS 5508-58-7 for R \& D use (Aldrich), chloroform (Merck), double distilled water for HPLC (PT IPHA), methanol for HPLC (JT Baker), acetonitrile for HPLC (PT Bratachem), dried sambiloto herbs (Kebun Percobaan Manoko Lembang), New Zealand male rabbits (Faculty of Husbandry Universitas Padjadjaran).

\section{Preparation of sambiloto herbs infusion}

Prior to be used, sambiloto dried herbs was determined at Biology Department, Faculty of Mathematics and Natural Sciences Universitas Padjadjaran. Thirty grams of dried herbs were boiled in water for $15 \mathrm{~min} 95^{\circ} \mathrm{C}$ (Hembing, 2008), filtered using cloth and kept in airtight container.

\section{Thin layer chromatography}

Thin layer chromatography was performed to detect andrographolide in sambiloto herbs infusion. A mixture of chloroform-methanol (9:1) was used as mobile phase. Sambiloto infusion was eluted on silica gel plate and detected under UV light at 254nm (Sukardiman, 2005).

\section{HPLC}

Optimization

Two hundred $\mu \mathrm{g} / \mathrm{L}$ of andrographolide standard in methanol was injected into C-18 (250mm, particle size $5 \mathrm{~m}$ ) column, with a mixture of methanol: double distilled water (65:35) as mobile phase. Flow rate was $1 \mathrm{~mL} / \mathrm{min}$ and detection was set at $223 \mathrm{~nm}$. Parameters observed were resolution, time of retention and tailing factor (Kumaran et al., 2002).

\section{Validation of Bioanalytical Method}

A mixture of rabbit plasma and methanol (1:5) was vortex-mixed for $2 \mathrm{~min}$ and centrifugated for $30 \mathrm{~min}$ at $3000 \mathrm{rpm}$. It was used for validation assay.

Linearity

Linearity is obtained by plotting concentration of andrographolide against area under curve. Supernatant was used to dilute andrographolide standard solution to obtain 0.5ppm; 1ppm; 2ppm; 4ppm; 6ppm; 8ppm; and $10 \mathrm{ppm}$ concentrations. All solutions were milipore-filtered and $20 \mu \mathrm{L}$ of each solution was injected into the C-18 column.

Precision

A $20 \mu \mathrm{L}$ diluted solution of $4 \mathrm{ppm}$ concentration was injected into the C-18 column. The procedure was repeated 10times and percentage of RSD was calculated for precision.

Accuracy

Twenty $\mu \mathrm{L}$ diluted solutions with concentrations of $2 \mathrm{ppm}, 6 \mathrm{ppm}$, and $10 \mathrm{ppm}$ were injected into the C-18 column. The procedure was repeated three times for each concentration and percentage of recovery was calculated for accuracy.

$\angle O D$ and $\angle O Q$

LOD and LOQ were calculated as followed (Harmita, 2004)

$$
\begin{aligned}
\mathrm{SD} & =\sqrt{\frac{(\mathbf{Y}-\mathbf{Y i})^{2}}{\mathbf{n}-\mathbf{2}}} ; \text { LOD }=\frac{3 \times \text { SD }}{\text { slope }} \\
\mathrm{OQ} & =\frac{10 \mathrm{xSD}}{\text { slope }}
\end{aligned}
$$




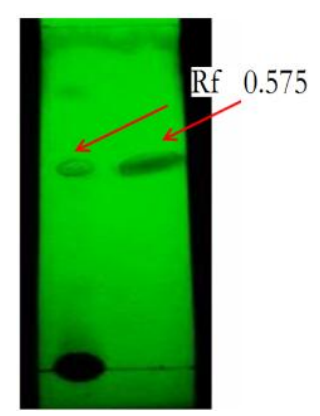

Figure 1. Thin layer chromatograms of andrographolide in sambiloto infusion (left) and andrographolide standard (right).
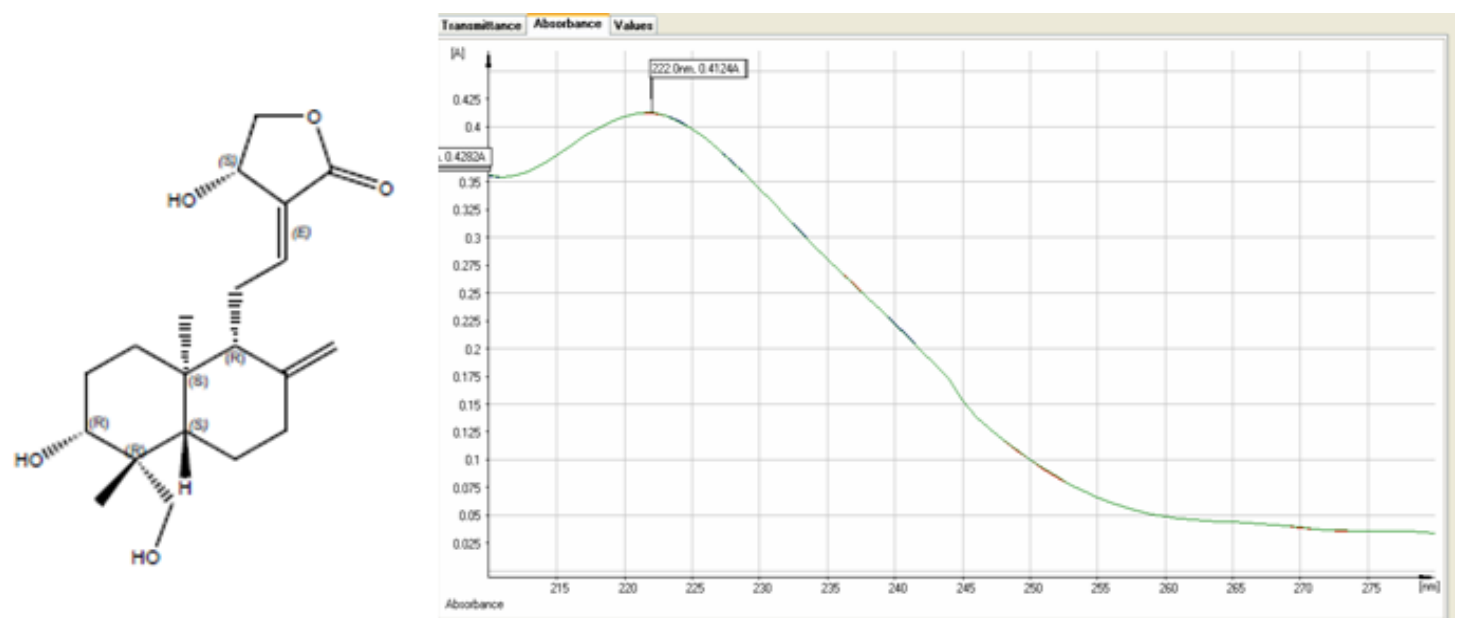

Figure 2. Andrographolide chemical structure (left) and UV spectrum in methanol (right)

\section{Bioavailability assay of sambiloto infusion herbs calculated as total andrographolide}

Fourteen New Zealand male rabbits (Oryctolagus cuniculus) aged four months old and weighed $1-1.5 \mathrm{~kg}$ were acclimatized for two weeks to adapt with the environment. Sambiloto herbs infusion with the dose of $7.04 \mathrm{~mL} / \mathrm{kg} \mathrm{BW}$ was given orally at day $15^{\text {th }}$. The blood was taken at interval of $0.0 ; 0.5 ; 1.5$; 2.0; 3.0; $5.0 \mathrm{~h}$ after sambiloto administration. Blood samples were kept in vacuette tubes containing anticoagulant and were centrifugated for $20 \mathrm{~min} 2000 \mathrm{rpm}$ to precipitate erythrocites and other proteins. Plasma was separated and diluted with methanol and milipore-filtered prior to be injected to the column. Rabbit stomaches were collected, washed and weighed, at interval $0.0 ; 0.5 ; 1.5 ; 2.0 ; 3.0 ; 5.0 \mathrm{~h}$ after sambiloto administration. The organs were crushed and homogenized using methanol as solvent (2mL of methanol for $200 \mathrm{mg}$ of the organ) and centrugated for $30 \mathrm{~min} 3000 \mathrm{rpm}$. Supernatant was separated and milipore-filtered prior to be injected to the column. Rabbit livers were collected, washed and weighed, at interval of $0.0 ; 0.5 ; 1.5 ; 2.0 ; 3.0 ; 5.0$ h after sambiloto administration. The organs were crushed and homogenized using methanol as solvent $(2 \mathrm{~mL}$ of methanol for $200 \mathrm{mg}$ of the organ) and centrifugated for $30 \mathrm{~min} 3000 \mathrm{rpm}$. Supernatant was separated and milipore-filtered prior to be injected to the column.

\section{RESULT AND DISCUSSION Thin layer chromatography}

Sambiloto infusion resulted purple spot similar to andrographolide at the Rf 0.575 (Figure 1). 

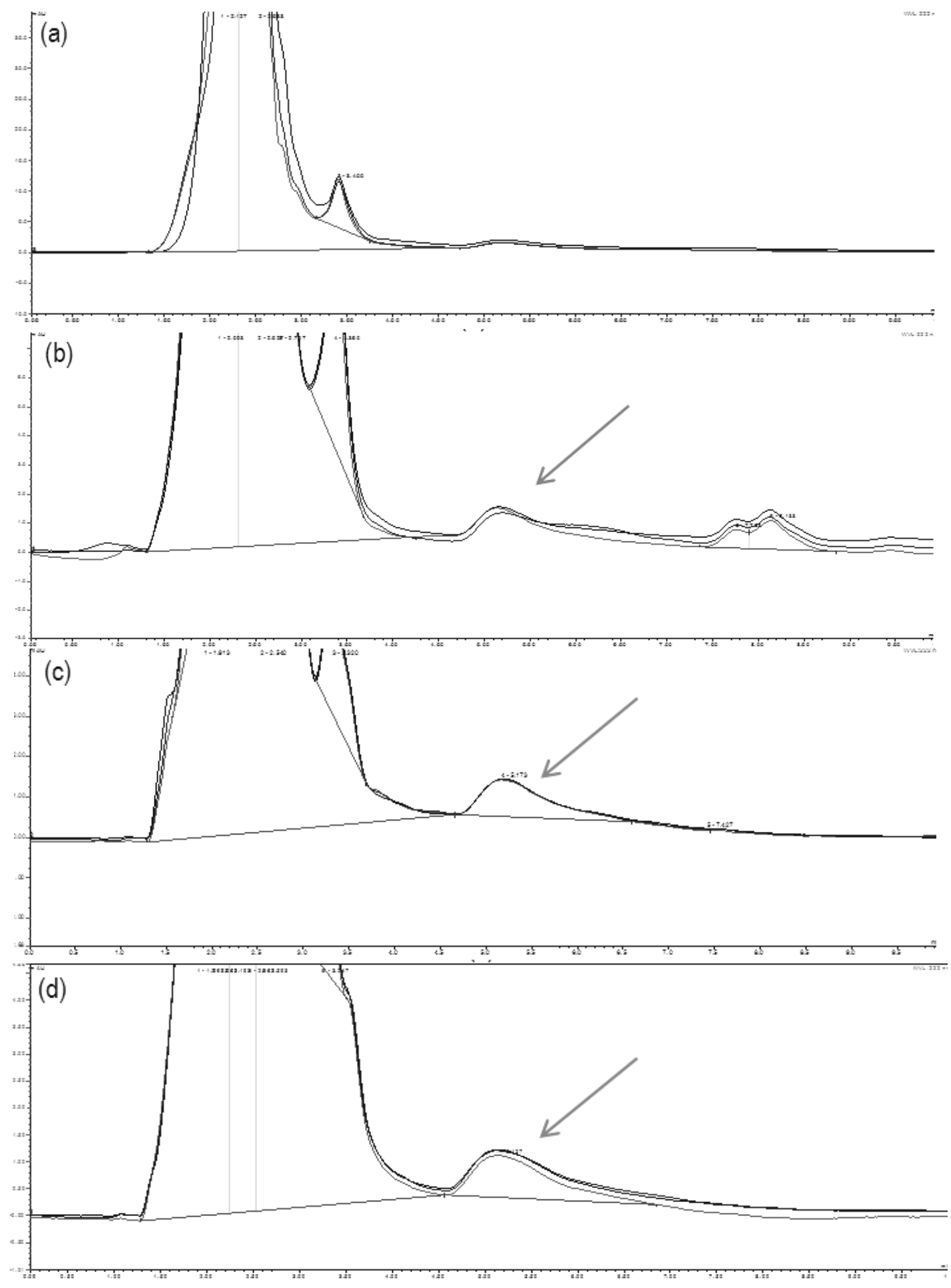

Figure 3. HPLC system of andrographolide in biological matrix using methanol- $\mathrm{H}_{2} \mathrm{O}$ 60:40 (a) plasma blank (b) 1.5 hours after oral administration; (c) 3 hours after oral administration; (d) 5 hours after oral administration 


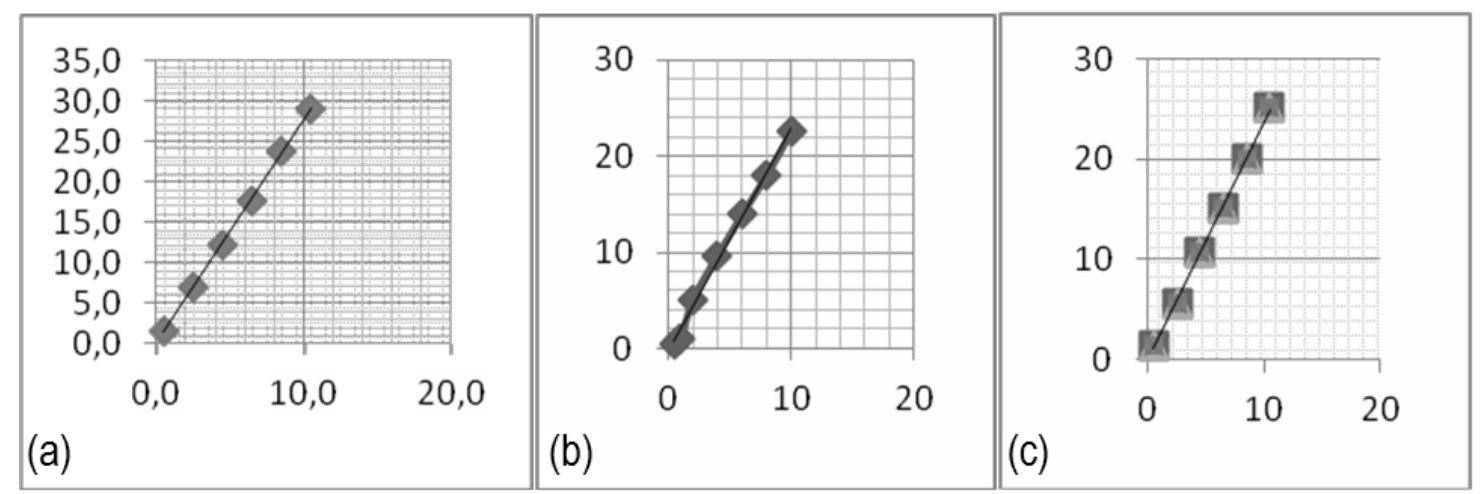

Figure 4. Linearity of andrographolide against detector response in rabbit plasma (a), stomach (b), and liver $(\mathrm{c})$

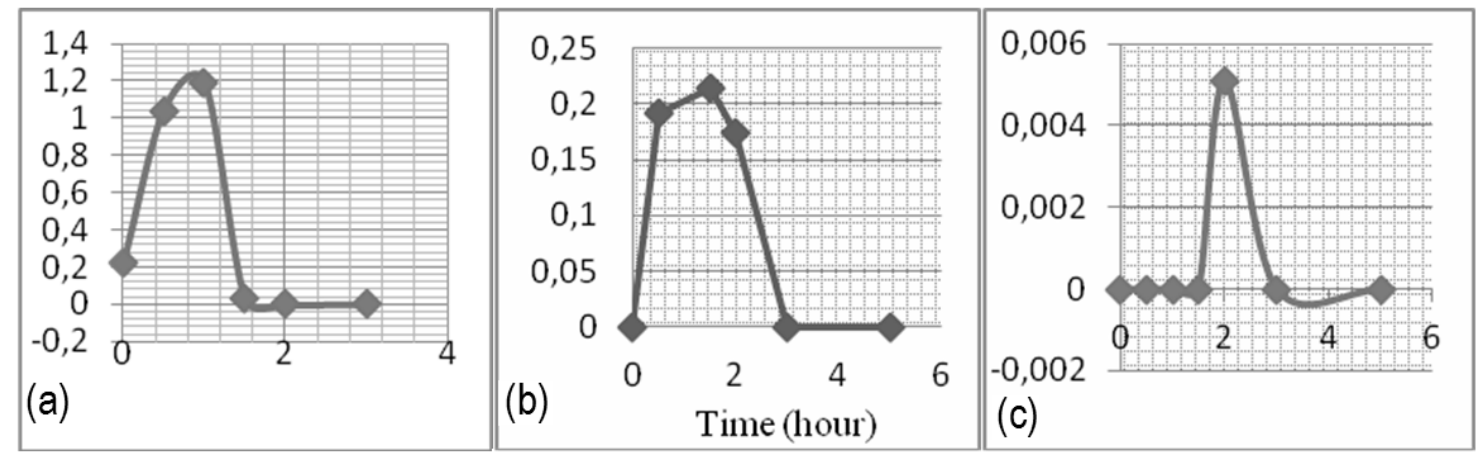

Figure 5. Pharmacokinetic profiles of andrographolide in rabbit plasma (a), stomach (b), liver (c)

Table I. Optimization of HPLC system

\begin{tabular}{cccc}
\hline \multirow{2}{*}{ Mobile phase } & \multicolumn{3}{c}{ Parameter } \\
\cline { 2 - 4 } & Resolution & Time of retention (minutes) & Tailing factor \\
\hline Methanol: $\mathrm{H}_{2} \mathrm{O}(65: 35)$ & 2.46 & 5.98 & 0.70 \\
Methanol: $\mathrm{H}_{2} \mathrm{O}(60: 40)$ & 3.2 & 7.66 & 0.98 \\
Methanol: $\mathrm{H}_{2} \mathrm{O}(55: 45)$ & 5.85 & 10.78 & 1.13 \\
\hline
\end{tabular}

Table 2. Bioavailability parameters of sambiloto infusion calculated as andrographolide

\begin{tabular}{cccc}
\hline Organ & Parameter & Value & \% absorbed \\
\hline \multirow{3}{*}{ Stomach } & $\mathrm{C}_{\max }$ & $1.1893 \mu \mathrm{g} / \mathrm{mL}$ & \multirow{2}{*}{$28.28 \%$} \\
& $\mathrm{t}_{\max }$ & $1 \mathrm{~h}$ & \\
& $\mathrm{AUC}$ & $2.4824 \mu \mathrm{g} \mathrm{h} / \mathrm{mL}$ & \multirow{2}{*}{$2.93 \%$} \\
\multirow{3}{*}{ Plasma } & $\mathrm{C}_{\max }$ & $0.2136 \mu \mathrm{g} / \mathrm{mL}$ & \\
& $\mathrm{t}_{\max }$ & $1.5 \mathrm{~h}$ & \\
& $\mathrm{AUC}$ & $0.4340 \mu \mathrm{g} \mathrm{h} / \mathrm{mL}$ & $0.05 \%$ \\
& $\mathrm{C}_{\max }$ & $0.0051 \mu \mathrm{g} / \mathrm{mL}$ & \\
\hline
\end{tabular}


The same $\mathrm{Rf}$ value shown (Figure 1 green arrows) indicated that andrographolide was positively contained in the infusion. The polar groups of Si-O attached on the surface of silica gel, retained andrographolide on the stationary phase, because the three hydroxyl groups at C3, C19, and C14 in its structure (Figure 2) could form hydrogen bonds.

\section{HPLC}

UV spectrum of andrographolide standard in methanol showed one peak at $222 \mathrm{~nm}$. This peak was elicited by $\pi \rightarrow \pi^{*}$ electronic transition of two olefin bonds at position C8-C9 and C11-C12 (Figure.2). Methanol itself shows absorption band at $190 \mathrm{~nm}$ due to $\mathrm{n} \rightarrow \sigma^{*}$ electronic transition of nonbonding electron of oxygen.

Good resolution was showed by Rs $>1.5$ (Gandjar and Rohman, 2007), therefore all three mixtures fulfilled the criteria.

The best composition of mobile phase selected for this analysis was a mixture of methanol-water (60:40) as the tailing factor was the closest to 1 (Figure 3 and Table I), meaning that the peak's symmetrical level is the best (Gandjar and Rohman, 2007).

\section{Validation of bioanalytical method}

Linearity study (Figure 4) indicated that there were good correlation between concentration of andrographolide and detector response for all three matrices (plasma $y=2.338 x-0.404$ and $r=0.994$; stomach $y=2.761 x+0.030$ and $r=0.999$; liver $y=2.364 x-0.009$ and $r=0.999$ ).

Accuracy and precision studies for all three matrices indicated that percentage of recovery fell in interval $97.06 \%$ to $102.25 \%$ while RSD value were 0.82 to $1.62 \%$, which meant that the method had high accuracy and precision.

LOD and LOQ were $1.87 \mathrm{ppm}$ and $5.44 \mathrm{ppm}$ (plasma) and $0.272 \mathrm{ppm}$ and $0.906 \mathrm{ppm}$ (stomach).

\section{Bioavailability assay of sambiloto infusion herbs calculated as total andrographolide}

Andrographolide was detected and quantified in the stomach less than an hour after administration (Figure $5 \mathrm{~b} \mathrm{t} t_{\max }=1 \mathrm{~h}$ ) and distributed in the circulation after one hour (Figure $\left.5 a t_{\max }=1.5 \mathrm{~h}\right)$. Itcould be observed and quantified $\mathrm{n}$ the liver two hours after administration (Figure $5 \mathrm{ct}_{\max }=2 \mathrm{~h}$ ). These data confirmed that andrographolide had good bioavailability because it was fastly absorbed from the stomach, directly distributed in the circulation and metabolized in the liver. These facts were probably caused by the three hydroxyls in andrographolide molecule (Figure 2) which contributed to its hydrophilic character, while the diterpenoid rings caused its lipophilicity. Drugs will be absorbed during two hours after administration depends on food intake and activity (Holford, 1998).

Andrographolide is a bicyclic diterpenoid which is slightly soluble in water $(3.29 \pm 0.73$ $\mu \mathrm{g} / \mathrm{mL})$. This compound has moderate lipophilicity $(\log \mathrm{P}=2.632 \pm 0.135)$, and easily hydrolyzed in weak base to neutral environment (Bothiraja et al., 2009a, b). Previous study concluded that the percentage of andrographolide absorbed was $0.24 \%$ (Budipramana, 2009). In this work, the level of andrographolide in the stomach was the highest because the food (given $24 \mathrm{~h}$ before the animals were treated with sambiloto infusion) in the rabbits' stomach were slowly metabolized. It seemed that the food slowered the passive transporttation of andrographolide through stomach.

\section{CONCLUSION}

Sambiloto infusion herbs was fastly absorbed from the stomach, distributed in the circulation system, and metabolized in the liver, in subsequent process. It showed good bioavailability in rabbit.

\section{ACKNOWLEDGEMENT}

The authors wish to thank DIKTI for funding this research in 2011 grant.

\section{REFERENCES}

Abu-Ghefreh AA., Canatan H., Ezeamuzie CI. 2009. In vitro and in vivo anti-flamma-tory effects of andrographolide, Int. Immunopharmacology, 9(3): 313-318

Bothiraja C., Shinde MB., Rajalakshmi S., Pawar AP. 2009a. Evaluation of molecular pharmaceutical and in vivo properties of spray-dried isolated andrographolidePVP. J Pharm Pharmacol 61:1465-1472

Bothiraja C., Pawar AP., Shaikh KS., Sher P. 
2009b. Eudragit EPO based nanoparticles suspension of andrographolide: in vitro and in vivo. Nanosi Nanotech. Lett 10:156-164

Budipramana, Krisyanti. 2009. Penentuan Parameter Ketersediaan hayati Andrografolida dan Kurkumin dari Campuran Ekstrak Herba Sambiloto (Andrographis paniculata Nees.) dari Rimpang Kunyit (Curcuma domestica Val.) dalam Serum kelinci Menggunakan HPLC. Fakultas Farmasi Universitas Airlangga Departemen Farmakognosi dan Fitokimia. Abstrak.

Chereson R. 1996. Basic Pharmacokinetics Chapter 8: Bioavailability, Bioequivalence and Drug Selection. The Virtual University Press. Nebraska: 8-2;8-3.

Chiou WF, Chen CF, and Lin JJ. 2000. Mechanisms of suppression of inducible nitric oxide synthase (iNOS) expression in RAW 264.7 cells by andrographolide, Brit J Pharm, 129: 1553-1560

Choudhury RB., Poddar MK. 1984. Andrographolide and Kalmegh (Andrographis paniculata) Extract: In Vivo and In Vitro Effect on Hepatic Lipid Peroxidation. Methods.Find.Exp.Clin.Pharmacol.6Abstract

Food Drug Administration. 2001. Guidance For Industry: Bioanalytical Method Validation. U.S Department of Health and Human Service: 2-8.

Holford N. 1998. Clinical Pharmacokinetics: Drug Data Handbook. 3rd ed. New Zealand: ADIS Press Limited Auckland.

Kumaran S., Thirugnanasambantham P., Viswanathan S., Murthy., SR. 2002, An HPLC Method for The Estimation of Andrographolide in Rabbit Serum. Ind J
Pharm, 35: 109-112.

Panossian A., Hovhannisyan A., Mamikonyan G., Abrahamian H., Hambardzumyan E., et al., 2000. Pharmacokinetic and oral bioavailability of andrographolide from Andrographis paniculata fixed combination Kan Jang in rats and human. Phytomedicine 7:351-364

Pinthong T., Bungadidj C., Mounhong A., Koysooku R. 1991. HPLC Determination of Andrographolide, Neoandrographolide and Dehydro-andrographolide in Biological Fluids. Siriraj Hosp Gar, 43(10): 763

Satyanarayana C., Deevi DS., Rajagopalan R., Srinivas N., Rajagopal S., 2004. DRF 3188 a novel semi-synthetic analog of andrographolide: cellular response to MCF7 breast cancer cells, BMC Cancer, 4(26): 1-8

Shen Y-C., Chen C-F., Chiou W-F., 2002. Andrographolide prevents oxygen radical production by human neutrophils: possible mechanisms involved in its antiinflammatory effect, Brit J Pharm, 135: 399-406

Sukardiman, Rahman A., Ekasari W., Sismindari. Induksi Apoptosis Andrografolida dari Sambiloto (Andrographis paniculata Nees) terhadap Kultur Sel Kanker. Media Kedokteran Hewan, 21(3): 107

Xia YF., Ye BQ., Li YD., Wang JG., He XJ., et al 2004. Andrographolide attenuates inflammation by inhibition of NF-kB activation through covalent modification of reduced cysteine 62 of $\mathrm{p} 50, \mathrm{~J} \mathrm{Imm}$, 4207-42 